\title{
Production of biologically active human interleukin-10 by Bifidobacterium bifidum BGN4
}

\author{
Nayoun Hong ${ }^{1}$, Seockmo Ku², Kyungjin Yuk ${ }^{3}$, Tony V. Johnston ${ }^{2}$, Geun Eog ji ${ }^{1,3^{*}}$ and Myeong Soo Park ${ }^{3^{*}}$ (i)
}

\begin{abstract}
Background: Bifidobacterium spp. are representative probiotics that play an important role in the health of their hosts. Among various Bifidobacterium spp., B. bifidum BGN4 exhibits relatively high cell adhesion to colonic cells and has been reported to have various in vivo and in vitro bio functionalities (e.g., anti-allergic effect, anti-cancer effect, and modulatory effects on immune cells). Interleukin-10 (IL-10) has emerged as a major suppressor of immune response in macrophages and other antigen presenting cells and plays an essential role in the regulation and resolution of inflammation. In this study, recombinant B. bifidum BGN4 [pBESIL10] was developed to deliver human IL-10 effectively to the intestines.
\end{abstract}

Results: The vector PBESIL10 was constructed by cloning the human IL-10 gene under a gap promoter and signal peptide from Bifidobacterium spp. into the E. coli-Bifidobacterium shuttle vector pBES2. The secreted human IL-10 from B. bifidum BGN4 [pBESIL10] was analyzed by sodium dodecyl sulphate-polyacrylamide gel electrophoresis (SDS-PAGE), Western Blotting, and enzyme-linked immunosorbent assay (ELISA). More than $1,473 \pm 300 \mathrm{ng} / \mathrm{mL}(n=4)$ of human IL-10 was obtained in the cell free culture supernatant of B. bifidum BGN4 [pBESIL10]. This productivity is significantly higher than other previously reported human IL-10 level from food grade bacteria. In vitro functional evaluation of the cell free culture supernatant of B. bifidum BGN4 [pBESIL10] revealed significantly inhibited interleukin-6 (IL-6) production in lipopolysaccharide (LPS)-induced Raw 264.7 cells $(n=6, p<0.0001)$ and interleukin-8 (IL-8) production in LPSinduced HT-29 cells $(n=6, p<0.01)$ or TNFa-induced HT-29 cells $(n=6, p<0.001)$.

Conclusion: B. bifidum BGN4 [pBESIL10] efficiently produces and secretes significant amounts of biologically active human IL-10. The human IL-10 production level in this study is the highest of all human IL-10 production reported to date. Further research should be pursued to evaluate B. bifidum BGN4 [pBESIL10] producing IL-10 as a treatment for various inflammation-related diseases, including inflammatory bowel disease, rheumatoid arthritis, allergic asthma, and cancer immunotherapy.

Keywords: Human interleukin-10, Bifidobacterium bifidum, Secretion, Bioactive, Recombinant, Expression vector

*Correspondence: geji@snu.ac.kr; bifidopark@bifido.com

${ }^{3}$ Research Center, BIFIDO Co., Ltd, Hongcheon 25117, Korea

Full list of author information is available at the end of the article

\section{Introduction}

Bifidobacterium spp. are Gram-positive, anaerobic, naturally occurring microorganisms that rapidly colonize the large intestine of breastfeeding infants and fermentative bacteria that have gained commercial and scientific interest. They have several health-promoting properties, such as the treatment and prevention of gastrointestinal disorders [1], reduction of lactose intolerance [2], protection against pathogens, enhancement of the immune system [3], and cancer prevention [4-6]. Also, several in vitro or

(c) The Author(s) 2021. This article is licensed under a Creative Commons Attribution 4.0 International License, which permits use, sharing, adaptation, distribution and reproduction in any medium or format, as long as you give appropriate credit to the original author(s) and the source, provide a link to the Creative Commons licence, and indicate if changes were made. The images or other third party material in this article are included in the article's Creative Commons licence, unless indicated otherwise in a credit line to the material. If material is not included in the article's Creative Commons licence and your intended use is not permitted by statutory regulation or exceeds the permitted use, you will need to obtain permission directly from the copyright holder. To view a copy of this licence, visit http://creativeco mmons.org/licenses/by/4.0/. The Creative Commons Public Domain Dedication waiver (http://creativecommons.org/publicdomain/ zero/1.0/) applies to the data made available in this article, unless otherwise stated in a credit line to the data. 
in vivo experimental models have indicated the biosafety $[7,8]$ and benefits of Bifidobacterium, including the enhancement of the cell barrier function [9], intestinal immunomodulatory effects [10], the production of antimicrobial substances [11], and the prevention of obesity and allergy [12].

Among the various Bifidobacterium sp., B. bifidum BGN4 [13] was chosen as a host in this study because of its proven in vitro and in vivo probiotic functionalities such as (i) high cell adhesion onto colon cells[14]; (ii) modulatory effects on macrophage cells and other immune cells [15]; (iii) anti-allergic responses in mouse models [16]; (iv) its potential for use as a treatment of anti-inflammatory bowel disease [17]; and (v) inhibition of cancer cell line growth [18]. Moreover, B. bifidum BGN4 is designated as generally recognized as a safe (GRAS) and certified by the US FDA (GRAS Notice \#814) [19], so it is regarded as safe for the expression and delivery of biologically active genes for human use. However, one of the major problems in transforming Bifidobacterium is that as a Gram-positive cell, Bifidobacterium spp. have thick cell walls which reduce transformation efficiency. To overcome this technical issue, we recently reported optimized electroporation conditions, including overcoming the restriction and modification system through GpC Methyltransferase treatment and cell wall weakening through $\mathrm{NaCl}$ [20-22]. Through our newly developed transformation protocol, several genes have been cloned and expressed using B. bifidum BGN4 as a host. Specifically, bifidobacterial $\beta$-galactosidase [20] was expressed in B. bifidum BGN4 and used to reduce lactose in milk and $\beta$-glucosidase was expressed and used in the conversion of isoflavone glucosides [23], disaccharides, and ginsenosides [24, 25].

Human IL-10 is a non-covalent homodimer in its biologically active form that dissociates into a stable but inactive monomer at pHs below 5.5 [26]. IL-10 acts as a major suppressor of immune response in macrophages and other antigen presenting cells (APCs) associated with the induction of signal transduction and activation of transcription 3 (STAT3) phosphorylation. IL-10 is known to target diverse cells and act as an anti-inflammatory cytokine. Specifically, IL-10 inhibits the transcription of proinflammatory cytokines and control LPS-induced glucose uptake and glycolysis [27-29]. IL-10 is also known to induce epithelial cell proliferation, promote wound repair, and play a critical role in intestinal homeostasis by its anti-inflammatory activities [30], limit thermogenesis and energy expenditure, and decrease inflammatory responses in adipocytes [31]. IL-10 has the potential to treat cancer and human autoimmune diseases, such as inflammatory bowel disease (IBD) [32, 33] and rheumatoid arthritis [28, 33]. According to a recent report, IL-10 was shown to stimulate the immune response instead of suppressing it [28]. However, secondary side effects could be avoided by using lower doses than those used in systemic treatment (intravenous injection, $>20 \mu \mathrm{g} / \mathrm{kg}$ ) of normal people [33, 34].

In previous studies, the mucosal administration of recombinant $L$. lactis secreting $\mathrm{IL}-10$ reduced $50 \%$ of colitis induced by the administration of dextran sodium sulfate (DSS) or DiNitro-Benzene Sulfonic-acid (DNBS) in mice $[32,35,36]$. A number of studies using recombinant $L$. lactis secreting IL-10 in IBD have proven that the topical treatment of cytokine IL-10 has clinical benefits in vivo [32, 33, 37]. However, the systemic administration of recombinant bacteria secreting human IL-10 (hIL10) has not demonstrated significant clinical benefits when compared with placebo groups in chronic disease patients (ClinicalTrials.gov Identifier: NCT00729872) [38], which is due to the low final concentration of recombinant hIL-10 in the gastrointestinal tract [33, 39]. Therefore, an objective of this research was to achieve high level expression of hIL-10 in B. bifidum BGN4.

In this study, to maximize the immune-modulatory activity of $B$. bifidum BGN4 as a probiotic cell strain, recombinant $B$. bifidum BGN4 [pBESIL10] was developed to deliver a significant level of human IL-10 directly to the intestines. Human IL-10 was extracellularly expressed in B. bifidum BGN4 using a gap promoter, a signal peptide from Bifidobacterium, and shuttle vector pBES2 by BGN4 [pBESIL10]. In addition, the production level and biological activity of the recombinant human IL-10 was evaluated in vitro.

\section{Materials and methods}

Bacterial strains, culture and bacterial growth experiment Escherichia coli DH5 $\alpha$ was routinely cultivated in LuriaBertani broth (LB) (BD Difco ${ }^{\mathrm{TM}}$, Sparks, MD, USA) or LB agar ( $1 \%$ of bacto agar was added) at $37^{\circ} \mathrm{C}$ overnight, and $100 \mu \mathrm{g} / \mathrm{mL}$ ampicillin was added when necessary [40]. B. bifidum BGN4 was routinely grown in de-MannRogosa-Sharpe broth (MRS) (BD Difco ${ }^{\mathrm{TM}}$ ) supplemented with $0.05 \%(\mathrm{w} / \mathrm{v}) \mathrm{L}$-cysteine. $\mathrm{HCl}$ at $37^{\circ} \mathrm{C}$ overnight under anaerobic conditions, and $3 \mu \mathrm{g} / \mathrm{mL}$ chloramphenicol was added for recombinant BGN4. For the production of human IL-10, recombinant BGN4 was cultured in a $1.2 \mathrm{~L}$ jar fermenter in a $\mathrm{pH}$-controlled MRSC (MRS with $0.05 \%(\mathrm{w} / \mathrm{v}) \mathrm{L}$-cysteine $\mathrm{HCl}$ and $3 \mathrm{ug} / \mathrm{mL}$ chloramphenicol added) broth.

To produce $\mathrm{pH}$-sensitive hIL-10, recombinant $B$. bifidum BGN4 [pBESIL10] was cultured overnight in $120 \mathrm{~mL}$ of MRSC medium, after which the cells were harvested and resuspended in 1.2 $\mathrm{L}$ of fresh MRS broth (pH 6.5). Then, B. bifidum BGN4 [pBESIL10] was cultured until reaching $\mathrm{pH} 6.0$, and an ammonia solution 
was added to maintain the $\mathrm{pH}$ at 6.8 . The bacteria were inoculated at $10 \%(\mathrm{v} / \mathrm{v})$, sampled after two hours, and thereafter bacterial suspensions were collected every hour for $10 \mathrm{~h}$. Bacterial cell growth was monitored by reading $\mathrm{OD}_{600 \mathrm{~nm}}$ spectrophotometrically using a spectrophotometer (Molecular Devices, San Jose, CA, USA).

\section{Manipulations of nucleic acids Oligonucleotides}

The promoter sequence of the gap gene was obtained from the Bifidobacterium longum genome database (GenBank AD052817). The signal peptide gene was obtained from Bifidobacterium bifidum S17 (GenBank NC_014616.1). The target hIL-10 gene fragments were codon-optimized to Bifidobacterium bifidum produced by a commercial supplier (IDT DNA, Coralville, IA, USA). The vector $\mathrm{pBES} 2$ was used for the shuttle vector between $E$. coli and B. bifidum. The vector pBES2 was constructed from a cryptic plasmid pMG1 from Bifidobacterium longum MG1 ligated to pUC19 and possessed ampicillin and chloramphenicol resistance markers [41]. The constructed pBESIL10 was proven to be the right vector by sequence processing conducted by a commercial supplier (Macrogen, Seoul, South Korea). The primers used for the In-Fusion Kit Polymerse Chain Reaction (PCR) (Takara Bio, Tokyo, Japan) were designed with the Takara In-Fusion Cloning Tool.

\section{Preparation of nucleic acids}

Plasmids were extracted with the Plasmid Purification Mini Kit (Nucleogen, Si-heung, South Korea) using sodium dodecyl sulfate (SDS) cell lysis and ethanol precipitation. In the case of $B$. bifidum transformants, titrated lysozyme diluted to $20 \mathrm{mg} / \mathrm{mL}$ with $10 \mathrm{mM}$ tris$\mathrm{HCl}$ added to the bacterial pellet. After the extraction and purification of the pBES2 shuttle vector, the restriction enzymes $\mathrm{XbaI}$ and Acc65I (Bio Labs, Ipswich, MA, USA) were used to linearize it. Agarose gel electrophoresis was used to analyze the DNA molecule via size determination and purify the PCR products via a Nucleogen Gel Extraction Kit. The agarose powder was dissolved in $1 \mathrm{X}$ TAE buffer (40 mM Tris- $\mathrm{HCl}, 10 \mathrm{mM}$ acetic acid, 1 mM EDTA, pH 8.0). The samples were loaded with 6 $\mathrm{X}$ loading star (Dyne Bio, Seongnam, South Korea) and either a Dyne $100 \mathrm{bp}$ or a Dyne $1 \mathrm{~kb}$ DNA ladder (Dyne Bio) was used as a size marker. The purified samples were qualified and quantified by broad-range (BR) assay via an Invitrogen Qubit 4 Fluorometer (Thermofisher Scientific) and a Nano spectrophotometer (Nano-400, Allsheng, Hangzhou, China).

\section{Polymerse chain reaction}

PCR was employed for amplifying the target genes, connecting them as one plasmid, and screening the transformants for cloned inserts [42]. PCR was performed on a SimpliAmp $^{\mathrm{TM}}$ Thermal Cycler (Thermofisher Scientific, Waltham, MA, USA). PrimeSTAR GXL DNA Polymerase (Takara Bio) was used for GC-rich gene amplification. The annealing temperature and elongation time were optimized for each primer pair, hIL-10 ORF Forward 5'-AGC CCC GGT CAG GGC-3', and hIL-10 ORF Reverse 5'-TCA ATT CCT AAT TTT CAT CGT CA-3'. After the gene fragments were prepared, they were connected as one plasmid using the In-Fusion HD Cloning kit (Takara Bio) without DNA ligase. As there were more than two fragments, including the linearized vector, the homologous region of the primer and gene fragment was made to be about $20 \mathrm{bp}$ at the $5^{\prime}$ end of the particular DNA strand. The PCR conditions were determined by the primer pairs: for Pgap, Pgap Forward, 5'-TGA TAA TAA GGG TAC TCT AGA GAT CTG GGG AAT GCC TCG-3', and Pgap Reverse, 5'-GAC CGG GGC TAT CCG CTG CGT TGG CCG TG-3'; for $h I L-10$ ORF, hIL-10 ORF Forward, 5'-CCA CGG CCA ACG CAG CGG ATA GCC CCG GTC AGG GCA-3' and hIL-10 ORF Reverse, 5'-GGT ACC CGG GGA TCC TCT AGT AAT GCC AAC TTT GTA CAA GAA AGC-3'. After PCR cycling was completed, chemo-transformation was conducted on E. coli DH5 $\alpha$ (Transgen Biotech, Beijing, China). The PCR was also used to screen the transformants from among other bacteria with $2 \times$ EmeralAmp GTPCR Master Mix (Takara Bio). The primers, Ligation Forward 5'-TTA AAT ATC TCT TTT CTC-3' and Ligation Reverse $5^{\prime}$-TCA ATT CCT AAT TTT CAT CGT CA-3', were used to screen whether the plasmid was properly constructed.

\section{Construction of PBESIL 10}

Bifidobacterium-E. coli shuttle vector pBES2 was constructed using a cryptic plasmid from B. longum MG1 ligated with pUC19 to possess ampicillin and chloramphenicol resistance markers [41]. pBES2 was cut by XbaI and Acc65I. The promoter with the signal peptide and hIL10 ORF with a terminator were amplified via PCR and connected with vector $\mathrm{pBES} 2$ via In-fusion cloning PCR.

\section{Plasmid transformation to Bifidobacteria}

Plasmid DNA extracted from E. coli DH5 $\alpha$ was methylated by $\mathrm{GpC}$ (M.CviPI) methyltransferases (NEB, Ipswich, MA, USA) and purified using a Nucleogen Gel Extraction Kit. After the pBESIL10 was constructed via Infusion PCR, restriction enzymes (Xba1, Acc65I) were used to confirm whether the plasmid was correctly 
transformed into E. coli DH5 $\alpha$. Electrocompetent B. bifidum BGN4 was prepared and transformed according to the method of Park et al. [21, 22]. After culturing the recombinant bacteria on a MRSC agar plate for $36 \mathrm{~h}$, the colonies formed on the selective plates were extracted and sequenced with primers from a commercial supplier (Macrogen) to determine whether they were the correct transformants.

\section{Expression of human interleukin-10 Protein production and separation}

For the production of hIL-10, BGN4 [pBESIL10] was cultured in MRS broth in a $1.2 \mathrm{~L}$ jar fermenter at $\mathrm{pH} 6.8$. As a control group, BGN4 [pBES2] without hIL-10 was cultured under the same conditions. The bacteria were inoculated at $10 \%(\mathrm{v} / \mathrm{v})$, sampled after two hours, and thereafter bacterial suspensions were collected every hour for $10 \mathrm{~h}$. After measuring the $\mathrm{OD}_{600 \mathrm{~nm}}$ value, the sampled bacterial suspensions were immediately centrifuged (13,000 rpm, $10 \mathrm{~min}$ ).

Five options to precipitate the protein from the cell free culture supernatant (CFCS) were evaluated (TCA, acetone, ethanol, TCA ethanol, amicon precipitation, and chloroform methanol); chloroform methanol precipitation was chosen for further experiments because the other methods did not produce detectable IL-10. The protein was extracted from CFCS with 4 volumes of methanol, 1 volume of chloroform, and 3 volumes of distilled water, and centrifuged $(14,000 \mathrm{~g}, 1 \mathrm{~min})$. After centrifugation, the aqueous layer of the mixture was removed, 4 volumes of methanol was added, and it was centrifuged again $(14,000 g, 2 \mathrm{~min}) . \mathrm{MeOH}$ was removed via speed-vacuum (Labo Gene, Copenhagen, Denmark) and the residual was dissolved in a RIPA buffer (Elpis Biotech, Daejeon, South Korea).

To detect intracellular hIL-10, the cell pellets were resuspended in TNT buffer $(50 \mathrm{mM}$ Tris- $\mathrm{HCl}, \mathrm{pH} 8$, $300 \mathrm{mM} \mathrm{NaCl}, 0.1 \%$ Triton X-100) and treated with $5 \mathrm{mg} / \mathrm{mL}$ lysozyme diluted in $20 \mathrm{mM}$ Tris- $\mathrm{HCl}$ for one hour at $37{ }^{\circ} \mathrm{C}[43,44]$. The resuspended cell pellets were centrifuged $(10,000 \mathrm{~g}, 3 \mathrm{~min})$ and washed three times. The washed cell pellets were resuspended in TNT buffer and sonicated (5 min, 1-0-1-0 pulse). The sonicated solutions were centrifuged (10,000 g, $10 \mathrm{~min})$ and dissolved in RIPA buffer (Elpis Biotech).

\section{ELISA analysis}

A sandwich enzyme-linked immunosorbent assay (ELISA) was used to assess the amount of human intrleukin-10 (hIL-10), mouse IL-6, and human IL-8 secreted in the CFCS of recombinant bacteria, the HT-29 cell, and Raw 264.7 cell supernatants. The routinely grown BGN4 [pBESIL10] and BGN4 [pBES2] in MRSC at $37{ }^{\circ} \mathrm{C}$ overnight $(18 \mathrm{~h})$ under anaerobic conditions of $120 \mathrm{~mL}$ culture broth were harvested by centrifugation. Then, all of the pellets were inoculated into individual $1.2 \mathrm{~L}$ of fresh MRS broth (pH 6.5) at $10 \%(\mathrm{v} / \mathrm{v})$ at $37{ }^{\circ} \mathrm{C}$. The bacterial supernatants were collected every hour and analyzed with a BD OptEIA ${ }^{\mathrm{TM}}$ kit (BD Biosciences, San Jose, CA, USA). The cell supernatants were collected after $6 \mathrm{~h}$ or $4 \mathrm{~h}$ treatment. Anti-human IL-10, anti-mouse IL-6, and anti-human IL-8 monoclonal antibodies were used as capture antibodies. The cell supernatants were collected after being treated by the bacterial supernatants [45].

\section{Western blot analysis}

For protein quantification in extracts from the CFCS and cell pellets of the recombinant bacteria, Bradford Assays (Bio-Rad) were used. Total protein concentration was calculated by a standard curve using several dilutions of BSA standard solution. Western Blot analysis was conducted to confirm the expression of hIL-10 in B. bifidum BGN4 [pBESIL10]. The protein fractions from the CFCS and cell pellets were separated by SDS-PAGE and blotted onto a $15 \%$ PVDF membrane (Bio-Rad). A precision plus protein dual color standard (Bio-Rad) was used as a molecular weight ladder, and a recombinant human IL-10 protein (LS-Bio, Seattle, WA, USA) was used as a positive control. A human IL-10 monoclonal antibody (JES3-12G8, Thermofisher Scientific) diluted to 1:100 and Pierce Goat Anti-Rat IgG $(\mathrm{H}+\mathrm{L})$ peroxidase conjugated secondary antibody (31470, Thermofisher Scientific) diluted to 1:500 were used. Specific bands on the membrane were visualized with an enhanced chemiluminescence (ECL) solution from the Western Bright ECL Kit (Advansta, San Jose, CA, USA).

\section{Bioassay \\ Cell line, media, and culture condition}

Raw 264.7 KCLB 40071) and HT-29 (KCLB 30038) cell lines were purchased from the Korea Cell Line Bank (Seoul, South Korea). Raw 264.7 cells $\left(10^{6}\right.$ cells/well), and HT-29 cells $\left(10^{6}\right.$ cells/well) were seeded into 24-well plates in Dulbecco's Modified Eagle's Medium (DMEM, Sigma-Aldrich) with $10 \%$ heat-inactivated fetal bovine serum (FBS, Welgene Inc., Daegu, South Korea) and 1\% antibiotic antimycotic solution (Sigma-Aldrich) and cultured for two to three days at $37{ }^{\circ} \mathrm{C}$ in an atmosphere of $5 \% \mathrm{CO}_{2} / 95 \%$ air.

\section{MTT cell viability assay}

The mitochondria-dependent reduction of MTT (3-[4,5-dimethylthiazol-2-yl]-2,5 diphenyl-2H-tetrazolium bromide) to formazan was performed to evaluate the effect of CFCS on the viability of the cells. Raw 264.7 cells were prepared at $100 \mu \mathrm{L}$ of $10^{6}$ cells $/ \mathrm{mL}$ for each 
well in 96-well plates at $37{ }^{\circ} \mathrm{C}$ in an atmosphere of $5 \%$ $\mathrm{CO}_{2} / 95 \%$ air for $24 \mathrm{~h}$. Thereafter, the cells were treated with CFCS with and without $1 \mu \mathrm{g} / \mathrm{mL}$ LPS for $24 \mathrm{~h}$. After removing the cell culture supernatant solutions, 100 $\mu \mathrm{L}$ of a diluted MTT solution $(5 \mathrm{mg} / \mathrm{mL}$ of MTT solution in PBS buffer diluted in DMEM 1:10) was added to each well and they were incubated for three hours. Then, $50 \mu \mathrm{L}$ of dimethyl sulfoxide (DMSO) was added to each well to solubilize the formazan. The optical density was measured at $570 \mathrm{~nm}$ via a microplate reader (Molecular Devices).

\section{Evaluation of anti-inflammatory effects of B. bifidum BGN4 [pBESIL 10]}

The cultured cells were stimulated with $100 \mathrm{ng} / \mathrm{mL}$ or $1 \mu \mathrm{g} / \mathrm{mL}$ of lipopolysaccharide (LPS) (Sigma Aldrich) or $0.5 \mathrm{ng} / \mathrm{mL}$ of TNF $\alpha$ (PeproTech, Hamada, Israel). The cells were treated with $5 \%$ or $10 \%(\mathrm{v} / \mathrm{v})$ CFCS of recombinant bacteria BGN4 [pBES2] and BGN4 [pBESIL10] or a recombinant hIL-10 protein in a total volume of 500 $\mu \mathrm{L}$ for $6 \mathrm{~h}$ or $4 \mathrm{~h}$ of treatment. All samples were analyzed in triplicate. After incubation, cell culture supernatants were collected and stored at $-80^{\circ} \mathrm{C}$ until further analysis. The active recombinant human IL-10 protein was used as a control group. The effect of ten percent (v/v) of hIL-10 secreted by the BGN4 [pBESIL10] $10 \mathrm{~h}$ cultured group was similar to that of $150 \mathrm{ng} / \mathrm{mL}$ of rIL-10.

The presence of nitrite was determined in the cell culture media via a NO detection assay. One hundred $\mu \mathrm{L}$ of cell culture medium with an equal volume of Griess reagent (Thermofisher Scientific) in a 96-well plate was incubated at room temperature for $10 \mathrm{~min}$. Then, the absorbance was measured at $540 \mathrm{~nm}$ using a microplate reader (Molecular Devices). The amount of nitrite in the supernatant was calculated from a sodium nitrite $\left(\mathrm{NaNO}_{2}\right)$ standard curve. Also, the cell culture media were collected to determine the suppression of mIL- 6 and hIL- 8 by mIL- 6 and hIL-8 ELISA kits (BD Biosciences).

\section{Statistical analysis}

The values of hIL-10 (ng/mL) in the CFCS are the means of the replicate determinations \pm standard deviation. The other values are the means of the replicate determinations + standard deviation. The ELISA data was analyzed by the GraphPad Prism (Ver 8.0.1) using an ordinary oneway ANOVA test. The statistical differences were examined by Tukey's multiple comparison tests. The statistical significance was $p<0.05$.

\section{Results}

\section{Construction of pBESIL 10}

The promoter regions upstream of the gap gene (bbif_0612) encoding glyceraldehyde-3-phosphate dehydrogenase
(Pgap) were predicted using the BPROM online software tool (http://linuxl.softberry.com/BPROM), which was developed for bacterial promoter prediction based on the recognition motif of $E$. coli $\sigma^{70}$ type sigma factors. This analysis yielded a single promoter with a relatively high linear discrimination function (LDF) in front of gap when the default unchangeable threshold value equals 0.2.

According to prior research, the transcriptional activities of four different putative promoters have been assayed by $\beta$-glucuronidase activity [46]. The transcriptional activity of $\mathrm{P}_{\text {gap }}$ was found to be significantly higher than that of the other promoters $\left(\mathrm{P}_{\text {hup }}, \mathrm{P}_{\text {huxS }}, \mathrm{P}_{16 S}\right.$, $\left.P_{\text {rRNA }}\right)$ of B. bifidum. Since the promoter region of the gap gene of $B$. bifidum S17 yielded the highest transcriptional activity among the promoters tested, $\mathrm{P}_{\text {gap }}$ was used as a promoter of the plasmid in this study (data not shown).

According to prior research, the functionalities of various signal peptides from three bifidobacterial strains, $B$. bifidum S17, B. longum E18, and B. breve S27, have been tested based on phytase activities in the supernatants of B. bifidum S17 constructs [46]. Since the S6 signal peptide (bbif_1671) was the most effective protein secretion signal from B. bifidum S17, it was chosen as a signal peptide in this study (data not shown). The DNA sequences of the signal peptide S6 (bbif_1671) are:

ATGAAATCACTGATGAAAAAGGTTTTCGCTGCC GCCGCGGCGATTGCCA

CCG TAT TTGGAT TGGCTGCGACGACAG TCG CCACGGCCAACGCAGCGGAT

The amino acid sequence of the signal peptide S6 (bbif_1671) is:

MKSLMKKVFAAAAAIATVFGLAATTVATANA*AD

(The * indicates predicted cleavage sites)

The synthetic hIL-10 gene was designed by the preferred codons to be expressed in B. bifidum. The optimized synthetic hIL-10 gene is shown in Table 1 . The optimized gene had $79 \%$ identity with the original gene (Fig. 1).

\section{Confirmation of BGN4 [pBESIL10] and growth curve}

pBESIL10 was constructed as discussed in the Materials and Method section, and the map is presented in Fig. 2a and Table 1 . The size of the pBESIL10 is $8484 \mathrm{bp}$ and the organized plasmid secretes hIL-10 protein in the recombinant B. bifidum BGN4 [pBESIL10]. After the pBESIL10 was constructed via Infusion PCR, restriction enzymes (Xba1, Acc65I) were used to confirm whether the plasmid was correctly transformed into E. coli DH5 $\alpha$ (Fig. 2b). pBES2 digested with restricted enzymes was revealed as a fragment similar in size to pBES2 $(7.5 \mathrm{~kb})$, as the cut fragment was too small. However, pBESIL10 digested 
Table 1 Components of pBESIL10

\begin{tabular}{|c|c|}
\hline Oligonucleotides & Gene Sequences \\
\hline \multirow{8}{*}{$\begin{array}{c}\text { Gap promoter } \\
\text { (bbif_0612) }\end{array}$} & AGATCTGCGGAATGCCTCGCATCGAATCGCCGCAGGC \\
\hline & -35 \\
\hline & TGTACAGACATATTTGT TAGCGTRAACGAAATATGGCCG \\
\hline & -10 \\
\hline & TTTTATGCTCAAAGCAAGCGCGACACCGTTGCTCTAGTA \\
\hline & CAGACGGCGCATTACAGTAGACACTGTTGGTAAACAAAG \\
\hline & GCCATAGCGCATCCATGCGCAAACGGTCTACCCTACAAA \\
\hline & GGGAG CTCGAG \\
\hline \multirow{3}{*}{$\begin{array}{c}\text { Signal } \\
\text { sequence } \\
\text { (bbif_1761) }\end{array}$} & ATGAAATCACTGATGAAAAAGGTTTTCGCTGCCGCCGCG \\
\hline & GCGATTGCCACCGTATTTGGATTGGCTGCGACGACAGTC \\
\hline & GCCACGGCCAACGCAGCGGAT \\
\hline \multirow{13}{*}{$\begin{array}{c}\text { Human } \\
\text { Interleukin-10 } \\
\text { optimized to } B \text {. } \\
\quad \text { bifidum }\end{array}$} & AGCCCCGGTCAGGGCACGCAGAGCGAAAATAGCTGTAC \\
\hline & GCATTTCCCCGGAAACCTGCCGAACATGCTGCGGGATCT \\
\hline & CCGTGACGCGTTTAGCCGTGTGAAGACGTTCTTTCAGAT \\
\hline & GAAGGACCAGCTGGATAACCTGCTCCTGAAGGAGAGCCT \\
\hline & CCTCGAGGATTTCAAAGGGTATCTCGGTTGTCAGGCTCT \\
\hline & GTCCGAAATGATTCAATTTTACCTCGAAGAGGTGATGCC \\
\hline & CCAGGCGGAAAACCAAGATCCGGATATTAAAGCCCACGT \\
\hline & TAATAGCCTGGGCGAGAATCTGAAGACCCTCCGCCTGCG \\
\hline & TCTCCGCCGGTGCCACCGTTTCCTGCCCTGCGAAAACAA \\
\hline & GTCCAAAGCTGTGGAACAGGTTAAAAATGCTTTCAATAA \\
\hline & ACTCCAGGAGAAGGGAATTTATAAGGCGATGTCCGAATT \\
\hline & TGATATCTTTATCAACTACATCGAGGCGTACATGACGAT \\
\hline & GAAAATTAGGAATTGA \\
\hline \multirow{3}{*}{ Terminator } & GTTTTAGAGCTAGAAATAGCAAGTTAAAATAAGGCTAGT \\
\hline & CCGTTATCAACTTGAAAAAGTGGCACCGAGTCGGTGCTT \\
\hline & TTTTTCTAGACCCAGCTTTCTTGTACAAAGTTGGCATTA \\
\hline
\end{tabular}

with restricted enzymes appeared as two fragments: a $0.9 \mathrm{~kb}$ insert fragment and a $7.5 \mathrm{~kb}$ larger fragment.

BGN4 [pBESIL10] and BGN4 [pBES2] were collected every hour. The time that the bacteria were inoculated was $0 \mathrm{~h}$ in Fig. 3a. The recombinant bacteria BGN4 [pBESIL10] growth curve appeared similar to that of BGN4 [pBES2] (Fig. 3a). 


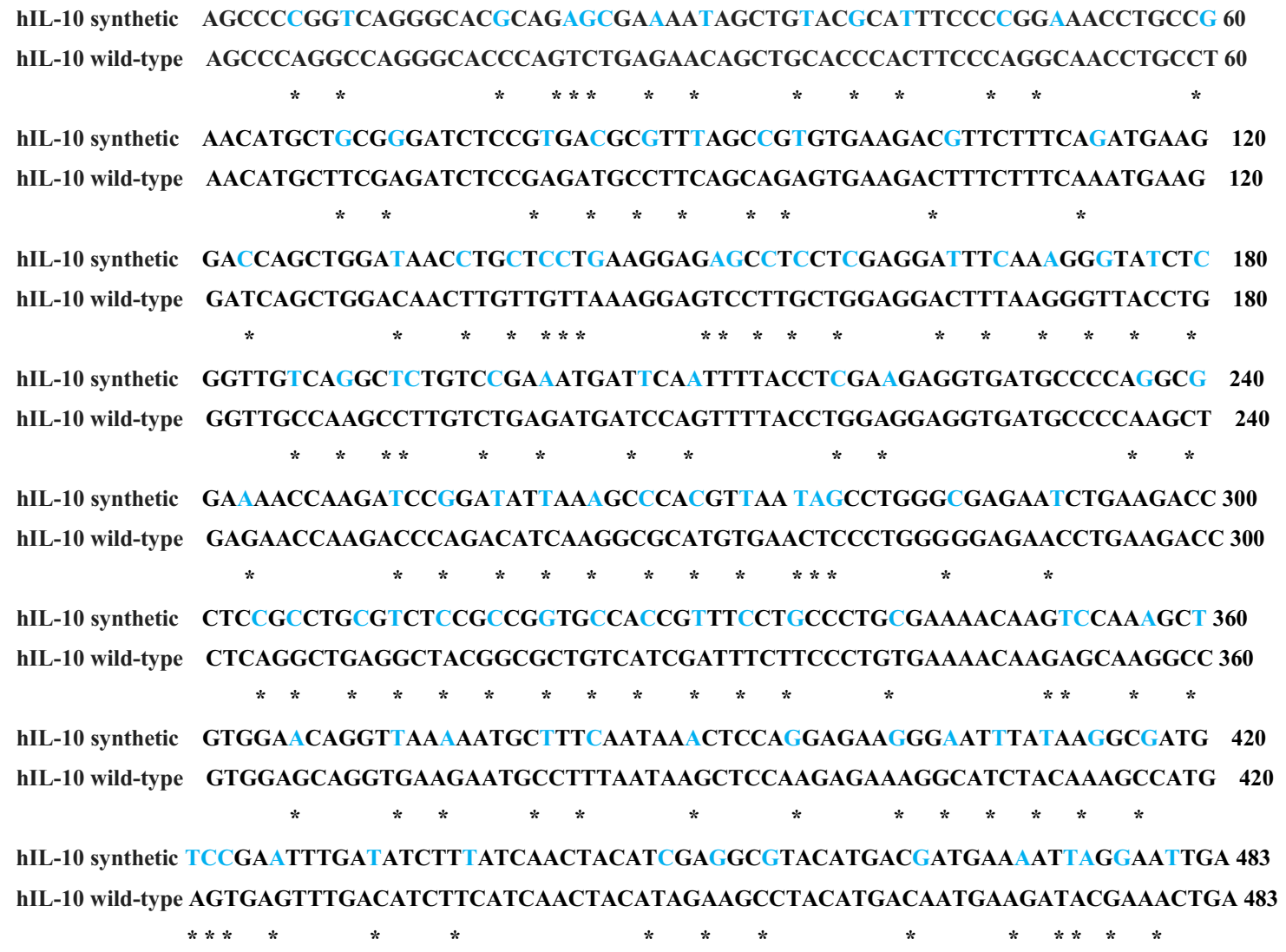

Fig. 1 Alignment of nucleotide sequences of the original and codon-optimized hIL-10 gene $\left(^{*}\right.$ is the modified sequence from the original hIL-10 gene during codon-optimization)

\section{Expression of recombinant hIL-10 ELISA}

The production of hIL-10 in the CFCS of recombinant $B$. bifidum BGN4 was measured by a BD ELISA kit according to the growth of recombinant BGN4 (Fig. 3a). The B. bifidum BGN4 [pBES2] cultured in buffered MRS for $10 \mathrm{~h}$ group was used as a negative control (Fig. $3 \mathrm{~b}$ ). $B$. bifidum BGN4 [pBESIL10] showed growth-associated production of hIL-10 $(n=4)$. The first bacteria supernatant $(2 \mathrm{~h})$ contained $128 \pm 46 \mathrm{ng} / \mathrm{mL}$ of hIL-10, the fifth bacteria supernatant $(6 \mathrm{~h})$ contained $956 \pm 129 \mathrm{ng} /$ $\mathrm{mL}$, and the last bacteria supernatant $(10 \mathrm{~h})$ contained $1473 \pm 300 \mathrm{ng} / \mathrm{mL}$ of hIL-10. Thus the $6 \mathrm{~h}$ to $10 \mathrm{~h}$ groups secreted a significantly larger amount of hIL-10. The $9 \mathrm{~h}$ and $10 \mathrm{~h}$ groups secreted significantly much more hIL-10 when compared with the $6 \mathrm{~h}$ group. During the $10 \mathrm{~h}$ of cultivation, the negative control showed hIL-10 concentrations below the detection limit.

\section{Western blot analysis}

The largest secretory production of hIL-10 in the CFCS of the BGN4 [pBESIL10] $10 \mathrm{~h}$ group was confirmed by
Western Blot. The CFCS of bacteria cultured for $10 \mathrm{~h}$ in buffered MRS was concentrated 40-fold by six different protein precipitation methods using TCA, acetone, ethanol, TCA ethanol, amicon precipitation, and chloroform methanol. Only the protocol using chloroform methanol showed the expected protein precipitation from the CFCS of BGN4 [pBESIL10]. The protein concentration of the extracted samples was quantified with a Bradford assay. According to the Bradford standard curve, the loading sample volumes were determined by $20 \mu \mathrm{g}$ of the total proteins. For low-concentration samples, $15 \mu \mathrm{L}$ of the samples were loaded depending on the maximum loading capacity. The CFCS of BGN4 [pBESIL10] precipitated with chlorophenol methanol was the only supernatant that exhibited the hIL-10 protein in the Western Blot (Fig. 3c).

\section{Bioassay \\ MTT assay-cell viability in raw 264.7 cells}

An MTT assay was used to analyze the effects of the CFCS of BGN4 [pBES2] and BGN4 [pBESIL10] cultured in buffered MRS media (Fig. 3b) as well as the 


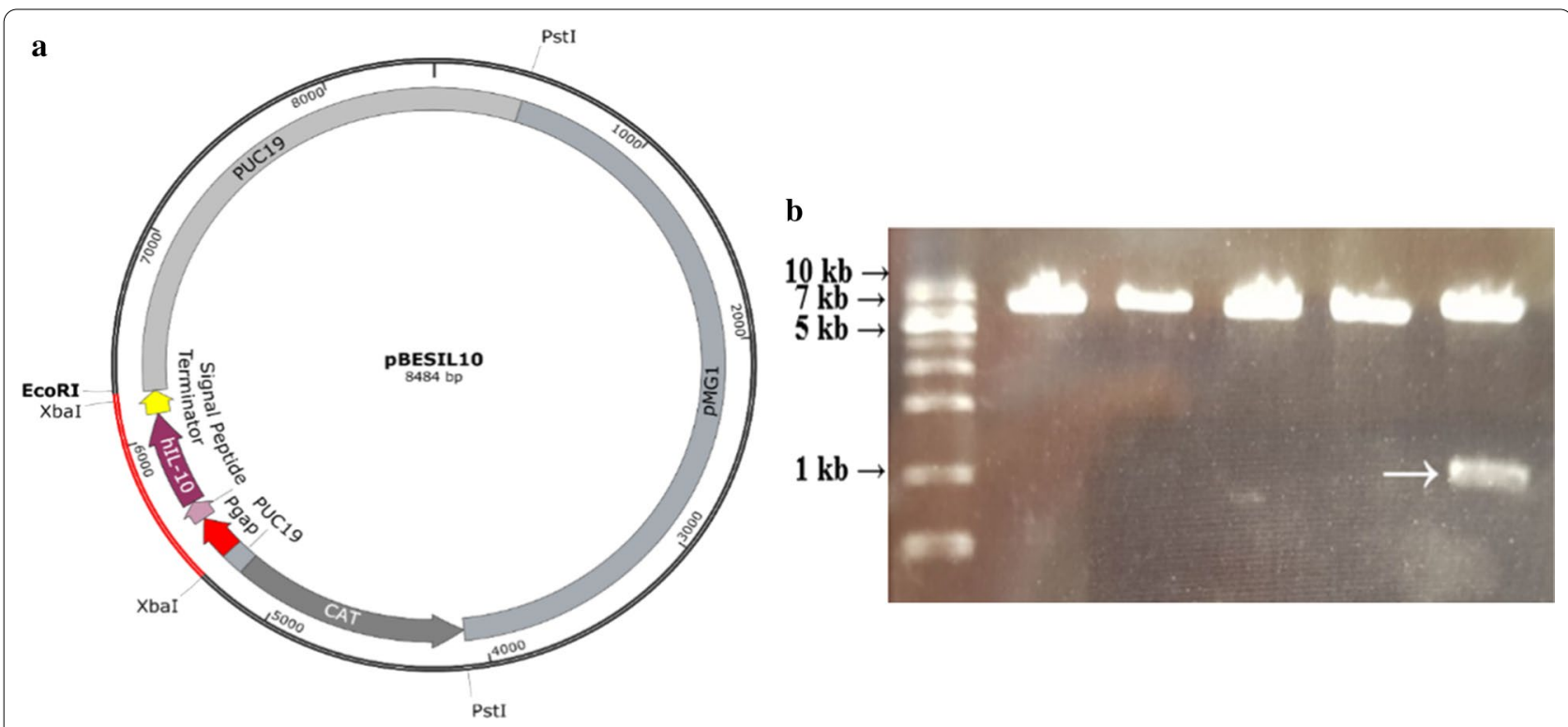

Fig. 2 a The structure of pBESIL10. b Restriction assay of pBES2 and PBESIL10. pBESIL10 is constructed with Pgap (gap promoter), the signal peptide of gene bbif_1761, hlL-10 (human Interleukin-10 ORF gene) optimized for Bifidobacterium bifidum, and terminator into pBES2. CmR and AmpR are chloramphenicol and ampicillin resistance genes; Ori is the origin of replication from pUC19; Mob and Rep are plasmid-encoded protein of MG1 from Bifidobacterium longum MG1 [38]. b Lane 1: 1 kb DNA ladder; Lane 2, 3, 4, 5: Xba1-Acc65l restriction of pBES2 shows one fragment (7.5 kb), as the other fragment is too small; Lane 6: Xba1-Acc65I restriction of pBESIL10 shows a 0.9 kb fragment (Insert fragment with Pgap, signal peptide, hIL-10 (optimized) and terminator connected, white arrow) with cut pBES2 (7.5 kb)

recombinant protein hIL-10 (rhIL-10) on Raw 264.7 cell viability. As the results in Fig. 4 show, hIL-10 production increased with time, especially for the $6 \mathrm{~h}$ to $10 \mathrm{~h}$ groups. Therefore, the cells were treated by the $6 \mathrm{~h}$ or $10 \mathrm{~h}$ group CFCS of BGN4 [pBES2] and BGN4 [pBESIL10], respectively. The Raw 264.7 cells $\left(10^{5}\right.$ cells/well) were treated by various CFCS with/without LPS for $24 \mathrm{~h}$ (Fig. 4a, b).

Figure 4a shows the cell viability of Raw 264.7 cells without LPS treatment. All cell viabilities treated with $10 \%(\mathrm{v} / \mathrm{v})$ of each CFCS were over $85 \%$ against the control (only MRS media $10 \%(\mathrm{v} / \mathrm{v})$ treated) $(n=6)$. Figure $4 \mathrm{~b}$ shows the cell viability of Raw 264.7 cells treated by each CFCS with $100 \mathrm{ng} / \mathrm{mL}$ of LPS. The cell viabilities treated with the samples and LPS were over $95 \%$ against the control (LPS $100 \mathrm{ng} / \mathrm{mL}$ with MRS 10\% (v/v)) $(n=6)$. MTT assay results showed no obvious cytotoxicity of CFCS of BGN4 [pBES2] and BGN4 [pBESIL10] or rhIL-10 after $24 \mathrm{~h}$ incubation in both the LPS-treated and LPSuntreated mouse macrophage.

\section{Inhibition of nitric oxide (NO) production in LPS-stimulated raw 264.7 cells}

Nitrite accumulation in the cells increased due to LPS treatment. Nitrite production was measured in the culture medium of the Raw $264.7\left(5 \times 10^{5} /\right.$ well $)$ murine macrophage cell line. Each of the cells were treated with the CFCS of B. bifidum BGN4 [pBES2] and B. bifidum
BGN4 [pBESIL10] and recombinant protein hIL-10 (Fig. 4c). The Raw 264.7 cells were activated by $100 \mathrm{ng} /$ $\mathrm{mL}$ of LPS, and NO production was measured as the nitrite concentration in the cell culture medium. The untreated control group exhibited nitrite concentration below the detection limit. Comparing the LPS group and the sample groups treated with LPS, the sample-treated groups released a significantly lower level of $\mathrm{NO}$ in the media $(n=6, p<0.0001)$. The CFCS of the recombinant bacteria showed a significantly higher reduction of nitrite accumulation in the LPS-stimulated Raw 264.7 cells.

\section{Inhibitory effect on the expression of pro-inflammatory cytokine IL-6 in LPS-stimulated raw 264.7 cells}

IL-6 is one of the pro-inflammatory cytokines that participates in the prolongation of chronic inflammation. The level of the cytokine production in LPS-induced macrophages was evaluated using ELISA. Raw 264.7 cells $\left(5 \times 10^{5} /\right.$ well $)$ treated with LPS $100 \mathrm{ng} / \mathrm{mL}$ for $6 \mathrm{~h}$ had significantly increased IL-6 production (Fig. 4d) compared to the untreated Raw 264.7 cells. The CFCS of BGN4 [pBESIL10] significantly suppressed the production of cytokine IL-6. The cells stimulated with LPS treated with the CFCS of BGN4 [pBESIL10] $6 \mathrm{~h}$ cultured group in buffered MRS and $10 \mathrm{~h}$ cultured group in buffered MRS (data not shown) for $6 \mathrm{~h}$ significantly suppressed the production of cytokine IL-6. BGN4 [pBESIL10] $(n=6, p<0.0001)$ was 

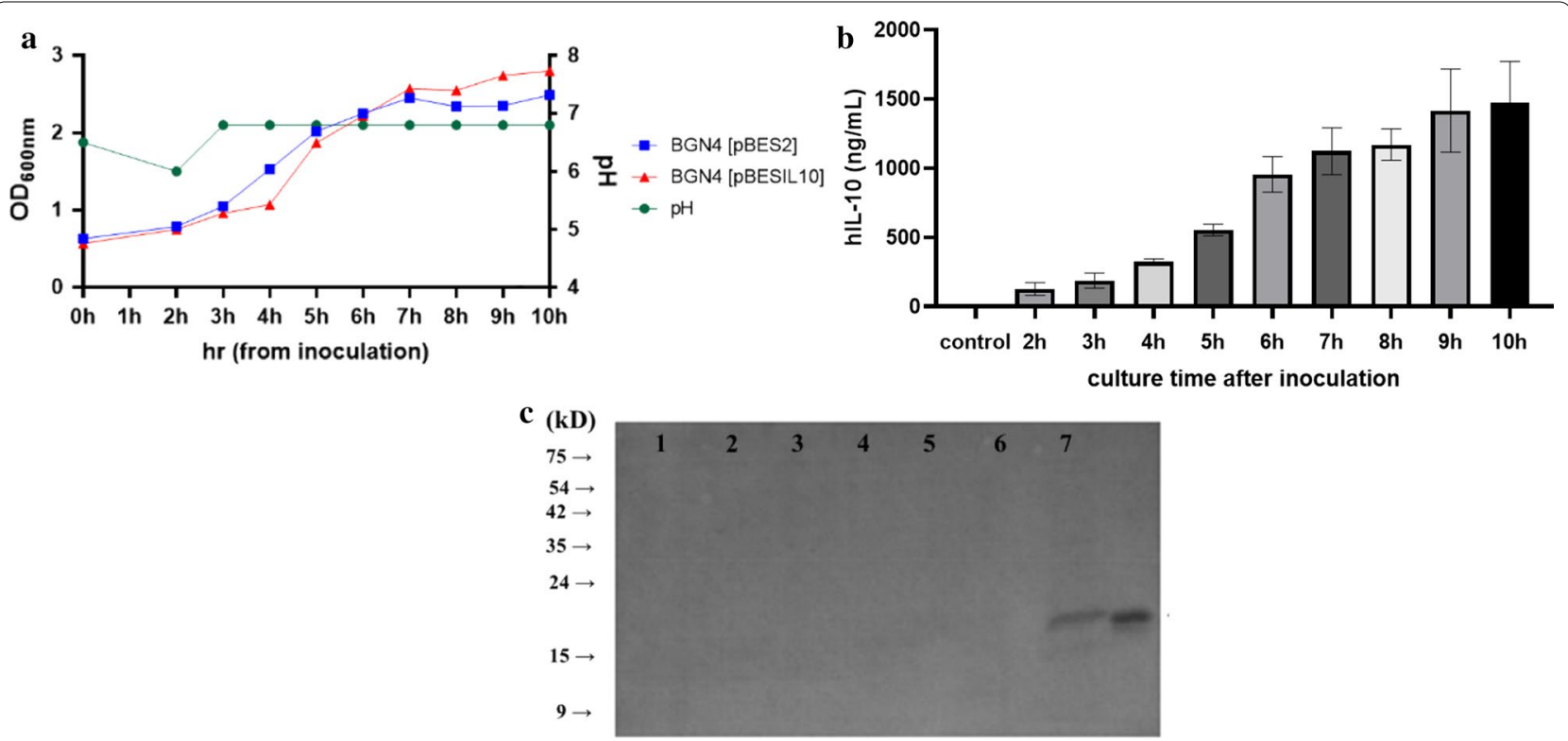

Fig. 3 Bacterial growth and hlL-10 production over time. a Culturing recombinant BGN4 graph at $\mathrm{OD}_{600 n m}$. b Quantification of hIL-10 produced by BGN4 [pBESIL10] Cell Free Culture Supernatant (CFCS) during culture in pH-controlled MRS medium by sandwich ELISA. (c) Western blot detection of human IL-10 protein. a The $120 \mathrm{~mL}$ of cultured recombinant bacteria were centrifuged and inoculated into $1.2 \mathrm{~L}$ of a fresh MRS broth (pH 6.5) at $0 \mathrm{~h}$ each. BGN4 cells were cultured until reaching a pH of 6.0, and a diluted ammonia solution was added to maintain a pH of 6.8 during the bacteria culture. $\mathbf{b}$ The $\mathrm{pH}$ was maintained at 6.8 during cultivation and the negative control BGN4 [pBES2] CFCS did not show detectable hIL-10 at the same condition. All data are shown as the mean \pm standard deviation $(n=4)$. The amount of hlL-10 were: $(2 \mathrm{~h}) 128 \pm 46 \mathrm{ng} / \mathrm{mL}$, ( $3 \mathrm{~h}) 189 \pm 54 \mathrm{ng} / \mathrm{mL}$, ( $4 \mathrm{~h})$ $327 \pm 20 \mathrm{ng} / \mathrm{mL}$, (5 h) $554 \pm 42 \mathrm{ng} / \mathrm{mL}$, ( 6 h) $956 \pm 129 \mathrm{ng} / \mathrm{mL}$, (7 h) 1,124 $\pm 170 \mathrm{ng} / \mathrm{mL}$, (8 h) 1,171 $\pm 114 \mathrm{ng} / \mathrm{mL}$, (9 h) $1,416 \pm 300 \mathrm{ng} / \mathrm{mL}$ and (10 h) $1,473 \pm 300 \mathrm{ng} / \mathrm{mL}$, respectively. (c) All CFCS were concentrated 40-fold by different precipitation methods. Lanes 1, 3, 5: BGN4 [pBES2] control strain grown in buffered MRS medium (pH 6.8); Lanes 2, 4, 6, 7: BGN4 [pBESIL10] strain grown in buffered MRS medium (pH 6.8); Lane C: positive control (recombinant hIL-10 protein (1 $\mu \mathrm{g})$ ); Lanes 1, 2: ethanol precipitation; Lanes 3, 4: acetone precipitation; Lanes 5, 7: chlorophenol methanol precipitation; Lane 6: TCA precipitation (other supernatant precipitation data and cell pellet data are not shown)

more effective in suppressing IL-6 production than BGN4 [pBES2] $(n=6, p<0.1)$ and $0.1 \mu \mathrm{g} / \mathrm{mL}$ of the recombinant hIL-10 protein $(n=6, p<0.0001)$.

\section{Inhibitory effect on the expression of pro-inflammatory cytokine IL-8 in LPS- or TNFa-simulated HT-29 cells}

IL-8 is one of the pro-inflammatory cytokines that participates in the prolongation of chronic inflammation. Cytokine production in LPS- and TNF $\alpha$-induced cells was evaluated using ELISA. The HT-29 cells $\left(5 \times 10^{5} /\right.$ well) treated with $1 \mu \mathrm{g} / \mathrm{mL}$ LPS or $0.5 \mathrm{ng} / \mathrm{mL}$ TNF $\alpha$ for $4 \mathrm{~h}$ showed a significant increase in IL- 8 production when compared to the untreated HT-29 cells. Figure 4e shows the CFCS of BGN4 [pBESIL10] $10 \mathrm{~h}$ cultured group $(n=6, p<0.01)$ in buffered MRS and BGN4 [pBES2] $10 \mathrm{~h}$ cultured group $(n=6, p<0.001)$ in buffered MRS significantly suppressed the production of cytokine IL-8. Figure $4 \mathrm{f}$ shows the CFCS of the BGN4 [pBESIL10] $10 \mathrm{~h}$ cultured group $(n=6, p<0.0001)$ in buffered MRS and BGN4 [pBES2] $10 \mathrm{~h}$ cultured group $(n=6$, $p<0.0001)$ in buffered MRS significantly suppressed the production of cytokine IL-8. Both were present at levels similar to the untreated HT-29 cells. However, $0.1 \mu \mathrm{g} / \mathrm{mL}$ of the recombinant hIL-10 protein did not suppress the production of cytokine IL-8.

\section{Comparing secretion of IL-10 with other recombinant probiotics}

Several previous studies involving genetically modified probiotics secreting IL-10 are shown in Table 2. Some secreted murine IL-10, which is not available in human studies, as the human IL-10 receptor does not bind with murine IL-10 [26, 29]. Specifically, L. lactis [pLB263] [47], L. lactis MG1363 [pT1MIL10] [44], B. bifidum $\mathrm{BS}_{2}$ [pBEST $\left._{\mathrm{SP} 1181}: \mathrm{IL}-10\right]$ [48], and B. bifidum BS42 [pBEST $\left._{\mathrm{SP1181}}: \mathrm{IL}-10\right]$ [48] secreted murine IL-10.

Also, there are some Bifidobacteria secreting IL-10, however, the amount is much lower that of BGN4 [pBESIL10]. For instance, a recombinant strain of B. longum ATCC 1507 [pLR] has been reported to produce $22 \mathrm{pg} / \mathrm{mL}$ of IL-10 [43]; B. breve [pESH100] produced $1900 \mathrm{pg} / \mathrm{mL}$ of hIL-10 [49];

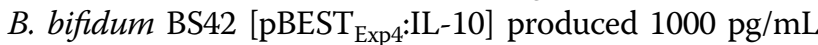
of mIL-10; B. bifidum BS42 [pBEST $\left.{ }_{\mathrm{SP} 1181}: \mathrm{IL}-10\right]$ produced $7000 \mathrm{pg} / \mathrm{mL}$ of mIL-10; and, at $\mathrm{pH}$ 8, B. bifidum BS42 

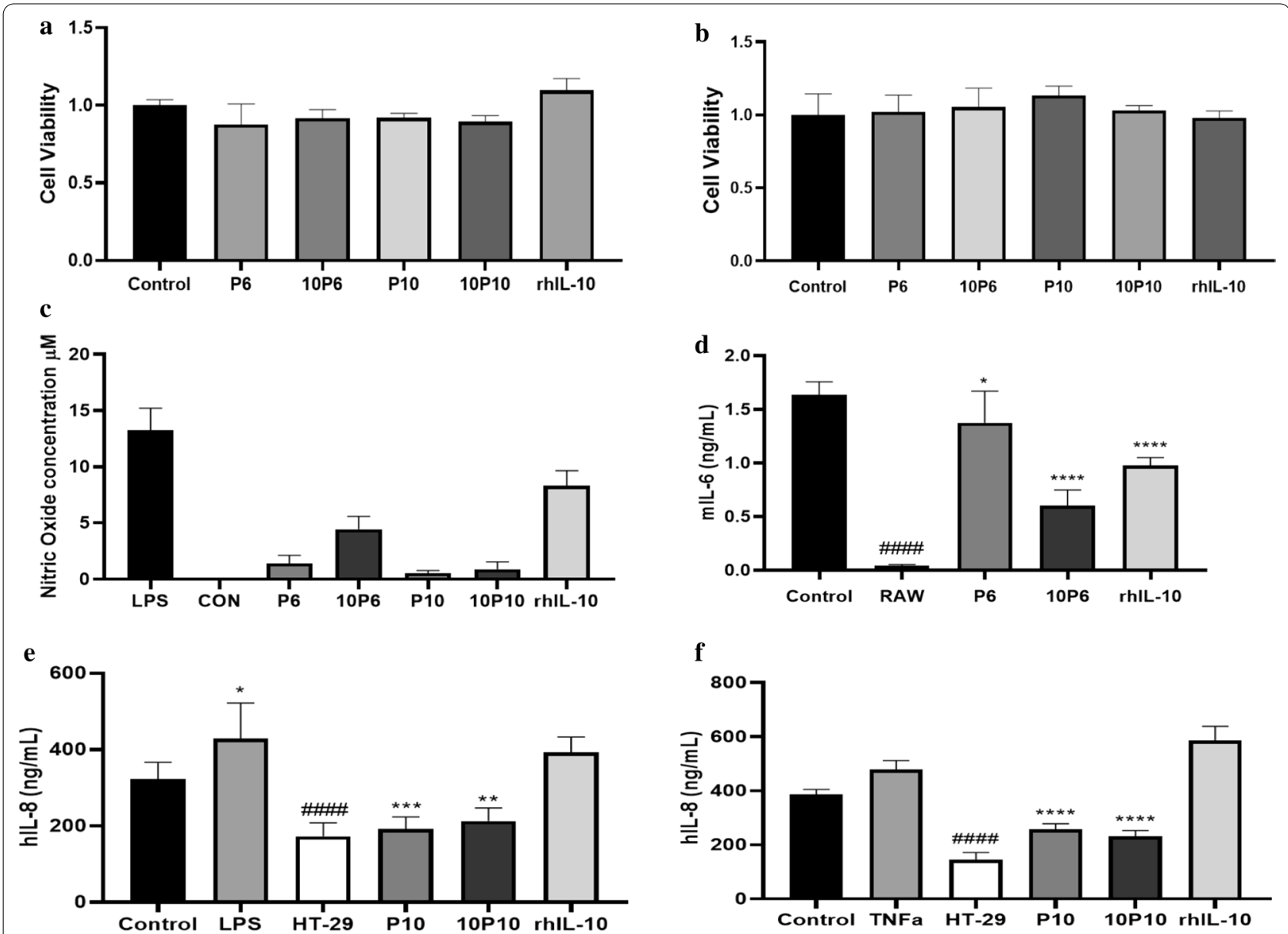

Fig. 4 Bioassay with Raw 264.7 cells and HT-29 cells treated with 10\% (v/v) cell free culture supernatant (CFCS) of BGN4 [pBES2] and BGN4 [pBESIL10] or rhIL-10 protein. rhIL-10 protein is an active recombinant human interleukin-10 protein, $150 \mathrm{ng} / \mathrm{mL}$ of which was similar to the $10 \%$ $(\mathrm{v} / \mathrm{V})$ of hIL-10 secreted by the BGN4[PBESIL10] $10 \mathrm{~h}$ cultured group. Viability of Raw 264.7 cells cultured in DMEM media for $24 \mathrm{~h}$ without LPS (a) and with $100 \mathrm{ng} / \mathrm{mL}$ of LPS (b). The inhibition of nitric oxide (NO) (c). The effects of CFCS of BGN4 [pBESIL10] on IL-6 production in (d) LPS-stimulated RAW 264.7 macrophage cells, IL-8 production in LPS- (e) or TNFa- (f) stimulated on HT-29 cells. Each data point represents the mean + standard deviation $(n=6)$. a, b Raw 264.7 cells (105/well) were treated with 10\% (v/v) CFCS of BGN4 [pBES2], BGN4 [pBESIL10] or rhIL-10 protein. Control: 10\% $(\mathrm{v} / \mathrm{v}) \mathrm{MRS} ; \mathrm{P} 6, \mathrm{P} 10$ : CFCS of BGN4 [pBES2] prepared at $6 \mathrm{~h}$ or $10 \mathrm{~h}$ of cultivation in buffered MRS; 10P6, 10P10: CFCS of BGN4 [pBESIL10] prepared at $6 \mathrm{~h}$ or $10 \mathrm{~h}$ of cultivation in buffered MRS; rhIL-10: $1 \mu \mathrm{g} / \mathrm{mL}$ of recombinant hlL-10 protein. There was no statistically significant difference among the treatment groups in both graphs with $p<0.05$. c, d Raw 264.7 cells $\left(5 \times 10^{5} /\right.$ well) were cultured in DMEM media for $6 \mathrm{~h}$ with $100 \mathrm{ng} / \mathrm{mL}$ of LPS and $10 \%(\mathrm{v} / \mathrm{v})$ CFCS of bacteria. c LPS: LPS $100 \mathrm{ng} / \mathrm{mL}$ treated only; P6, P10: CFCS of BGN4 [pBES2] prepared at $6 \mathrm{~h}$ or $10 \mathrm{~h}$ of cultivation in buffered MRS with LPS $100 \mathrm{ng} / \mathrm{mL} ; 10 P 6$, 10P10: CFCS of BGN4 [pBESIL10] prepared at $6 \mathrm{~h}$ or $10 \mathrm{~h}$ of cultivation in buffered MRS with LPS $100 \mathrm{ng} / \mathrm{mL} ; \mathrm{rhIL-10:} 1 \mu \mathrm{gg} /$ $\mathrm{mL}$ of recombinant hIL-10 protein with LPS $100 \mathrm{ng} / \mathrm{mL}$; CON: DMEM media only. Untreated control group exposure data was below the detection limit. For all samples: $p<0.0001$ (against LPS-stimulated group). $\mathbf{d}$ Control: 10\% (v/v) MRS; RAW: Raw 264.7 cells without any treatment; P6: CFCS of BGN4 [pBES2] $6 \mathrm{~h}$ cultivation in buffered MRS; 10P6: CFCS of BGN4 [pBESIL10] $6 \mathrm{~h}$ cultivation in buffered MRS; rhlL-10: $0.1 \mu \mathrm{g} / \mathrm{mL}$ of recombinant hIL-10 protein. e, f HT-29 cells $\left(5 \times 10^{5} /\right.$ well) were incubated in DEMEM culture media for $4 \mathrm{~h}$ with $5 \%(\mathrm{v} / \mathrm{v}) \mathrm{CFCS}$ of bacteria. Control: $5 \%$ (v/v) MRS; HT-29: HT-29 cells without any treatment; P10: CFCS of BGN4 [pBES2] $10 \mathrm{~h}$ cultivation in buffered MRS; 10P10: CFCS of BGN4 [pBESIL10] $10 \mathrm{~h}$ cultivation in buffered MRS; rhIL-10: recombinant hIL-10 protein $0.1 \mu \mathrm{g} / \mathrm{mL}$; LPS: LPS $1 \mu \mathrm{g} / \mathrm{mL}$; TNFa: TNFa $0.5 \mathrm{ng} / \mathrm{mL}$. \#\#\#\# $p<0.0001$, the control group versus the untreated group; ${ }^{*} p<0.1,{ }^{* *} p<0.01,{ }^{* * *} p<0.001,{ }^{* * * *} p<0.0001$, the treated group was significantly different from the control group

[pBEST $\left._{\mathrm{SP1181}}: \mathrm{IL}-10\right]$ overproduced mIL-10 24,000 pg/mL [48].

In our study, B. bifidum BGN4 [pBESIL10] produced the greatest amount of hIL-10 compared to those described with other plasmids with transformed probiotics, with a yield of $1,473 \pm 300 \mathrm{ng} / \mathrm{mL}$ of hIL-10. 
Table 2 Various recombinant probiotics secreting IL-10

\begin{tabular}{|c|c|c|c|c|c|}
\hline Probiotics & Protein & Vector & Promoter & amount & References \\
\hline L. lactis Thy 12 & Human IL-10 & Chromosome integrated & $P_{\text {thyA }}$ (constitutive) & $13.7 \mathrm{ng} / \mathrm{mL}$ & {$[35]$} \\
\hline L. lactis & Murine IL-10 & pLB263 & $P_{\text {groESL }}$ (Inducible) & $40.72 \mathrm{ng} / \mathrm{mL}$ & {$[45]$} \\
\hline L. lactis MG1363 & Murine IL-10 & pT1MIL10 & P1 (constitutive) & $630 \mathrm{ng} / \mathrm{mL}$ & {$[41]$} \\
\hline B. longum NCC2705 & Human IL-10 & pLR & $P_{\text {hup }}$ (constitutive) & $22 \mathrm{pg} / \mathrm{mL}$ & {$[40]$} \\
\hline B. breve UCC2003 & Human IL-10 & pESH100 & $P_{\text {gap }}$ (constitutive) & $1.9 \mathrm{ng} / \mathrm{mL}$ & {$[47]$} \\
\hline B. bifidum BS42 & Murine IL-10 & $\mathrm{pBEST}_{\text {Exp } 4}: \mathrm{IL}-10$ & $P_{\text {dnak }}$ (constitutive) & $7 \mathrm{ng} / \mathrm{mL}$ & {$[46]$} \\
\hline B. bifidum BS42 & Murine II-10 & $\mathrm{pBEST}_{\mathrm{SP} 1181}: \mathrm{IL}-10$ & $P_{\text {dnak }}$ (constitutive) & $24 \mathrm{ng} / \mathrm{mL}$ & {$[46]$} \\
\hline B. bifidum BGN4 & Human IL-10 & pBESIL10 & $P_{\text {gap }}$ (constitutive) & 1473 ng/mL & This study \\
\hline
\end{tabular}

\section{Discussion}

IL-10 has been well-documented as a major suppressor of the inflammatory immune response in diverse cells, and has been proven by various in vitro and in vivo studies $[29,30,50]$. There have been a number of studies using recombinant $L$. lactis and other Bifidobacterium-secreting IL-10 related to IBD treatment and clinic benefits [35, 43, 44, 46]. For example, recombinant Lactococcus lactis secreting hIL-10 in Crohn's disease was successful in phase 1 clinical trial. As the secretion of IL-10 by recombinant probiotic bacteria can be delivered directly to the intestine, the risk of degradation is small, and it is easy to increase the concentrations of IL-10 in the intestine [33]. In this study, human IL-10 was cloned and transformed into Bifidobacterium bifidum BGN4, and its successful expression and activity were proven by ELISA, Western Blot, and bioassay testing.

Macrophages and lymphocytes play a central role in immune response through the release of different cytokines, and the evaluation of the levels of cytokines and macrophage activity using an in vitro assay is considered an indirect way to analyze bio-functional effects of recombinant bacteria [51]. Through the MTT test of RAW 264.7 cells with and without LPS treatment, cell viability was determined not to be affected by the cell free culture supernatant (CFCS) of B. bifidum BGN4 [pBES2] and B. bifidum BGN4 [pBESIL10]. RAW 264.7 cells activated by LPS treatment produce nitric oxide (NO), which is an important mediator of macrophage phagocytosis [52]. The CFCS of BGN4 induced well-developed morphological changes in the macrophages and increased phagocytic activity, thus significantly reducing $\mathrm{NO}$ production [15]. Also, IL-10 limits basic microbicidal mechanisms, such as the production of NO in murine macrophages [53]. Therefore, B. bifidum BGN4 [pBES2] and B. bifidum BGN4 [pBESIL10] supernatants both significantly lower NO levels.

The recombinant $B$. bifidum BGN4 [pBESIL10] secreting human IL-10 also significantly lowered the inflammatory index (IL-6) in mouse RAW 264.7 cells. IL-6, which is a pro-inflammatory cytokine, has immunomodulatory effects, including the stimulation of B-cell differentiation and T-cell activation [54]. As the B. bifidum BGN4 supernatant was unable to affect IL-6 production $[15,55]$, the $B$. bifidum BGN4 [pBES2] supernatant could not reduce the IL- 6 production. As IL-10 could significantly inhibit IL-6 protein production at high concentrations of LPS treatment in macrophage cell lines [56], human IL-10 secreted by the B. bifidum BGN4 [pBESIL10] supernatant significantly inhibited IL-6 production in RAW 264.7 cells.

Bifidobacterium sp. inhibits IL-8 release in LPS-treated human colon adenocarcinoma (HT-29) cells, and these Bifidobacterium cell species may be good agents for preventing inflammation via neutralizing Gram-negative endotoxins and improving intestinal health $[10,57]$. IL-8, which is one of the proinflammatory cytokines produced in the intestine, initiates an acute inflammatory cascade and is an early marker of the inflammatory process [54]. IL-10 does not stimulate IL-8 generation and has no effect on IL- 8 production by LPS or TNF $\alpha$ induced the colonic epithelial cell line HT-29 [58]. The transcriptional control of IL-8 was mediated by transcription factor NF-кB in HT-29 cells, which is up regulated by TNF $\alpha$ [59]. However, hIL-10 affects both Th1 and Th2 and inhibits IL-8 production in human polymorphonuclear leukocytes (PMNs) and mononuclear cells (MNCs) [60]. The cytokine IL- 8 release is affected by Bifidobacterium spp. production of soluble anti-inflammatory factor ІкВ- $\zeta$ which inhibit NF-KB mediated IL-8 expression [59, 61]. Therefore, B. bifidum BGN4 [pBESIL10] and B. bifidum BGN4 [pBES2] CFCS significantly decreased the IL-8 release in HT-29 cells, since both are B. bifidum BGN4.

B. bifidum BGN4 [pBESIL10] is a bacterium with superior intestinal adhesion ability when compared to other recombinant bacteria [14], and it also has immunosuppression effects on macrophage cells [15]. In addition, the shuttle vector pBES2, which 
can be transformed into E. coli and Bifidobacterium [41], and the gap promoter [46, 62] with a signal peptide (bbif_1761) [62,63] which had high expression and excellent secretion ability from $B$. bifidum were used. Therefore, IL-10 may be more effective in the large intestine when delivered by this engineered bacterium versus those employed in previous studies. Also, in terms of detecting the amount of secreted human IL-10 with ELISA, we confirm that the B. bifidum BGN4 [pBESIL10] is able to produce and secrete higher hIL-10 levels than those previously reported for recombinant Bifidobacteria and L. lactis. In our study, we observed a consistent production of hIL-10 comparable or even greater than those described with other plasmids with transformed probiotics, with a yield of $1473 \pm 300 \mathrm{ng} / \mathrm{mL}$ of hIL-10. While conducting animal cell experiments, we were able to confirm the benefits of hIL-10 and the efficacies of B. bifidum BGN4 supernatant. Human IL-10 secreted by B. bifidum BGN4 [pBESIL10] into the supernatant significantly inhibited IL-6 production in RAW 264.7 cells, whereas the B. bifidum BGN4 supernatant did not affect IL-6 production. IL-10 does not stimulate or affect IL-8 production by LPS or TNF $\alpha$ induced by human colon adenocarcinoma HT-29 cells, however Bifidobacterium sp. inhibits IL-8 release in LPS-treated HT-29 cells.

Although the efficacies of recombinant bacteria through animal cells have been confirmed in this study, further studies are needed to determine whether the effect on the human body is significant using animal models and clinical experiments in vivo. Since cytokine IL-10 and B. bifidum BGN4 have been applied in various fields, they have also shown potential in treating human autoimmune diseases such as inflammatory bowel disease (IBD) [32, 33], cancer, rheumatoid arthritis [28, 33], and in the prevention of obesity and allergies [12]. Therefore, recombinant B. bifidum BGN4 [pBESIL10] can potentially be widely used. In addition, considering that the ecological activity area of L. lactis is the small intestine, while Bifidobacterium is largely resident in the large intestine, it is expected that synergic functional effects will occur when Lactococcus and Bifidobacterium are applied together as hosts [48]. Furthermore, the IL-27 with Blimp-1 could induce IL-10 in CD4 T cells downstream of STAT1/ STAT3 signaling, resulting in a broader immunosuppressive response [39, 64].

\section{Conclusion}

The objective of this study was the production and evaluation of a recombinant B. bifidum BGN4 which could deliver human IL-10 to the host intestines. As a plasmid construction process, a gap promoter and signal peptide from Bifidobacterium spp. and the human IL-10 gene optimized to Bifidobacterium were cloned into the E. coli-Bifidobacterium shuttle vector pBES2. More than $1473 \pm 300 \mathrm{ng} / \mathrm{mL}$ of human IL-10 was detected in the cell free culture supernatant of $B$. bifidum BGN4 [pBESIL10]. B. bifidum BGN4 [pBESIL10] efficiently produces and secretes significant amounts of biologically active human IL-10, and its production level is the highest of all human IL-10 production reported to the academic community to date. Further in vivo and clinical research should be pursued to evaluate therapeutic properties of B. bifidum BGN4 [pBESIL10] synthesizing IL-10 as a treatment for various inflammation-related diseases, including inflammatory bowel disease, rheumatoid arthritis, allergic asthma, and cancer immunotherapy.

\section{Acknowledgements}

Not applicable.

\section{Authors' contributions}

$\mathrm{NH}$ designed the experiment under the supervision of SK, GEJ and MSP. KY performed microbial fermentation experiments. NH, SK and MS Park performed the literature research and analyzed data. NH, SK and MS Park wrote and prepared original draft. NH, SK, TVJ and MSP edited and revised the manuscript together. SK and TVJ participated this work based on a non-disclosure research agreement between Middle Tennessee State University and BIFIDO Co., Ltd. All authors discussed drafts. All authors read and approved the final manuscript.

\section{Funding}

This work was carried out with the support of the Ministry of Small and Medium-sized Enterprises(SMEs) and Startups(MSS), Korea, under the "Regional Specialized Industry Development Program (R\&D, Project number S2848321)" supervised by the Korea Institute for Advancement of Technology(KIAT). This work was also supported by a Faculty Research and Creative Activity Committee (FRCAC) Grant (No. 221745) funded by Middle Tennessee State University in the U.S.

\section{Availability of data and materials}

The datasets used and/or analysed during the current study are available from the corresponding author on reasonable request.

Ethics approval and consent to participate Not applicable.

\section{Consent for publication}

Not applicable.

\section{Competing interests}

Nayoun Hong and Seockmo Ku and Tony V. Johnston declare no conflicts of interest. Kyungjin Yuk, Geun Eog Ji and Myeong Soo Park are directly employed by BIFIDO Co., Ltd. Geun Eog Ji and Myeong Soo Park hold BIFIDO Co., Ltd. stocks as a CEO and CTO, respectively.

\section{Author details \\ ${ }^{1}$ Department of Food and Nutrition, Research Institute of Ecology, SeoulNa- tionalUniversity, Seoul 08826, Korea. ${ }^{2}$ Fermentation Science Program, School of Agriculture, College of Basic and Applied Sciences, Middle Tennessee State University, Murfreesboro, TN 37132, USA. ${ }^{3}$ Research Center, BIFIDO Co., Ltd, Hongcheon 25117, Korea.}

Received: 26 July 2020 Accepted: 29 December 2020

Published online: 19 January 2021 


\section{References}

1. Snelling AM. Effects of probiotics on the gastrointestinal tract. Curr Opin Infect Dis. 2005:18(5):420-6.

2. Vesa TH, Marteau P, Korpela R. Lactose intolerance. J Am Coll Nutr. 2000;19(sup2):165S-175S.

3. Roller M, Rechkemmer G, Watzl B. Prebiotic inulin enriched with oligofructose in combination with the probiotics Lactobacillus rhamnosus and Bifidobacterium lactis modulates intestinal immune functions in rats. J Nutr. 2004;134(1):153-6.

4. Moubareck C, Gavini F, Vaugien L, Butel MJ, Doucet Populaire F. Antimicrobial susceptibility of Bifidobacteria. J Antimicrob Chemother. 2005;55(1):38-44.

5. Biavati B, Mattarelli P. Bifidobacterium Bergey's Manual of systematics of archaea and bacteria 2015; 1-57.

6. Turroni F, Duranti S, Bottacini F, Guglielmetti S, Van Sinderen D, Ventura M. Bifidobacterium bifidum as an example of a specialized human gut commensal. Front Microbiol. 2014;5:437-44.

7. Ku S, Yang S, Lee HH, Choe D, Johnston TV, Ji GE, Park MS. Biosafety assessment of Bifidobacterium animalis subsp. lactis AD011 used for human consumption as a probiotic microorganism. Food Control. 2019;117:106985

8. Kim MJ, Ku S, Kim SY, Lee HH, Jin H, Kang S, Li R, Johnston TV, Park MS, Ji GE. Safety evaluations of Bifidobacterium bifidum BGN4 and Bifidobacterium longum BORI. Int J Mol Sci. 2018;19(5):1422.

9. Ewaschuk JB, Diaz H, Meddings L, Diederichs B, Dmytrash A, Backer J, van Looijer Langen M, Madsen KL. Secreted bioactive factors from Bifidobacterium infantis enhance epithelial cell barrier function. Am J Physiol Gastrointest Liver Physiol. 2008;295(5):G1025-34.

10. Park MS, Kim MJ, Ji GE. Assessment of lipopolysaccharide-binding activity of Bifidobacterium and its relationship with cell surface hydrophobicity, autoaggregation, and inhibition of interleukin-8 production. J Microbiol Biotechnol. 2007;17(7):1120-6.

11. Wu MH, Pan TM, Wu YJ, Chang SJ, Chang MS, Hu CY. Exopolysaccharide activities from probiotic Bifidobacterium: immunomodulatory effects (on J774A. 1 macrophages) and antimicrobial properties. Int J Food Microbiol 2010;144(1):104-10.

12. Bienenstock J, Wiley RE, Neigh GS, Waserman S, Keith P. Probiotics in the management and prevention of atopy. Clin Rev Allergy Immunol. 2002;22(3):275-85.

13. Ku S, Park MS, Ji GE, You HJ. Review on bifidobacterium bifidum bgn4: Functionality and nutraceutical applications as a probiotic microorganism. Int J Mol Sci. 2016;17(9):1544.

14. Kim IH, Park MS, Ji GE. Characterization of adhesion of Bifidobacterium sp. BGN4 to human enterocyte-like Caco-2 cells. J Microbiol Biotechnol. 2003;13(2):276-81.

15. Kim NJ, Ji GE. Modulatory activity of Bifidobacterium sp. BGN4 cell fractions on immune cells. J Microbiol Biotechnol. 2006;16(4):584-9.

16. Lee $\mathrm{S}, \mathrm{Koo}$ N, Oh S. Regulatory effect on specific Ige response of Bifidobacterium bifidum (BGN4 Strain) in murine model of peanut allergy. J Allergy Clin Immunol. 2006;117(2):S204.

17. Kim N, Kunisawa J, Kweon MN, Ji GE, Kiyono H. Oral feeding of Bifidobacterium bifidum (BGN4) prevents CD4+ CD45RBhigh T cell-mediated inflammatory bowel disease by inhibition of disordered T cell activation. Clin Immunol. 2007;123(1):30-9.

18. You HJ, Oh DK, Ji GE. Anticancerogenic effect of a novel chiroinositolcontaining polysaccharide from Bifidobacterium bifidum BGN4. FEMS Microbiol Lett. 2004;240(2):131-6.

19. Administration USFaD. GRAS Notices GRN No. 814. https://www.fda.gov/ media/133875/download.

20. Park MJ, Park MS, Ji GE. Cloning and heterologous expression of the $\beta$-galactosidase gene from Bifidobacterium longum RD47 in B. bifidum BGN4. J Microbiol Biotechnol. 2019;29(11):1717-28.

21. Park MJ, Park MS, Ji GE. Improvement of electroporation mediated transformation efficiency for a Bifidobacterium strain to a reproducibly high level. J Microbiol Methods. 2019;159:112-9.

22. Park MJ, Park MS, Ji GE. Improvement of the electro-transformed cell yield for Bifidobacterium sp. with large DNA. Korean J Food Sci Technol. 2019;51(2):188-91.

23. You HJ, Ahn HJ, Kim JY, Wu QQ, Ji GE. High expression of $\beta$-glucosidase in Bifidobacterium bifidum BGN4 and application in conversion of isoflavone glucosides during fermentation of soy milk. J Microbiol Biotechnol. 2015;25(4):469-78.

24. Youn SY, Park MS, Ji GE. Identification of the $\beta$-glucosidase gene from Bifdobacterium animalis subsp. lactis and its expression in B. bifidum BGN4. J Microbiol Biotechnol. 2012;22(12):1714-23.

25. Kim JY, Wang Y, Park SJ, Ji GE, Park MS. Cloning and expression of $\beta$-glucosidases from Bifidobacterium lactis AD011. Food Sci Biotechnol. 2012;3(21):731-8

26. Syto R, Murgolo NJ, Braswell EH, Mui P, Huang E, Windsor WT. Structural and biological stability of the human interleukin 10 homodimer. Biochemistry. 1998;37(48):16943-51.

27. Ip WE, Hoshi N, Shouval DS, Snapper S, Medzhitov R. Anti-inflammatory effect of IL-10 mediated by metabolic reprogramming of macrophages. Science. 2017;356(6337):513-9.

28. Saraiva M, Vieira P, O'garra A. Biology and therapeutic potential of interleukin-10. J Exp Med. 2020;217(1):e20190418.

29. Moore KW, de Waal MR, Coffman RL, O'Garra A. Interleukin-10 and the interleukin-10 receptor. Annu Rev Immunol. 2001;19(1):683-765.

30. Kole A, Maloy KJ. Control of intestinal inflammation by interleukin-10. In: Interleukin-10 in health and disease. Springer; 2014; p. 19-38.

31. Mauer J, Chaurasia B, Goldau J, Vogt MC, Ruud J, Nguyen KD, Theurich S, Hausen AC, Schmitz J, Brönneke HS. Signaling by IL-6 promotes alternative activation of macrophages to limit endotoxemia and obesity-associated resistance to insulin. Nat Immunol. 2014;15(5):423-30.

32. Steidler L, Hans W, Schotte L, Neirynck S, Obermeier F, Falk W, Fiers W, Remaut E. Treatment of murine colitis by Lactococcus lactis secreting interleukin-10. Science. 2000;289(5483):1352-5.

33. Wang X, Wong K, Ouyang W, Rutz S. Targeting IL-10 family cytokines for the treatment of human diseases. Cold Spring Harbor Perspect Biol. 2019;11(2):a028548

34. Tilg H, Van Montfrans C, Van den Ende A, Kaser A, Van Deventer S, Schreiber S, Gregor M, Ludwiczek O, Rutgeerts P, Gasche C, Koningsberger J, Abreu L, Kuhn I, Cohard M, LeBeaut A, Grint P, Weiss G. Treatment of Crohn's disease with recombinant human interleukin 10 induces the proinflammatory cytokine interferon $\gamma$. Gut. 2002;50(2):191-5.

35. Robinson K, Chamberlain LM, Schofield KM, Wells JM, Le Page RW. Oral vaccination of mice against tetanus with recombinant Lactococcus lactis. Nat Biotechnol. 1997;15(7):653-7.

36. Martín R, Martín R, Chain F, Chain F, Miquel S, Miquel S, Natividad JM, Natividad JM, Sokol H, Sokol H. Effects in the use of a genetically engineered strain of Lactococcus lactis delivering in situ IL-10 as a therapy to treat low-grade colon inflammation. Human Vacc Immunother. 2014;10(6):1611-21.

37. Braat $H$, Rottiers $P$, Hommes DW, Huyghebaert $N$, Remaut $E$, Remon JP, Van Deventer SJ, Neirynck S, Peppelenbosch MP, Steidler L. A phase I trial with transgenic bacteria expressing interleukin-10 in Crohn's disease. Clin Gastroenterol Hepatol. 2006;4(6):754-9.

38. A Phase 2a Study to Evaluate the Safety T, Pharmacodynamics and efficacy of AG011 in ulcerative colitis. ClinicalTrials.gov Identifier: NCT00729872. https://clinicaltrials.gov/ct2/show/NCT00729872.

39. Olivia CG, Joaquin SF, Elena GF. Lactic acid bacteria: reviewing the potential of a promising delivery live vector for biomedical purposes. Microb Cell Fact. 2015;14(1):137.

40. Corry JEL, Curtis GDW, Baird RM. Handbook of culture media for food microbiology progress in industrial microbiology. Brain Heart Infusion. 2003;37:409-11.

41. Park MS, Moon HW, Ji GE. Molecular characterization of plasmid from Bifidobacterium longum. J Microbiol Biotechnol. 2003;13:457-62.

42. A short history of the polymerase chain reaction. ed. B. JMS, S. D. 2003 : 3-6.

43. Escogido MLR, Rodríguez ADL, de la Rosa APB. A novel binary expression vector for production of human IL-10 in Escherichia coli and Bifidobacterium longum. Biotechnol Lett. 2007;29(8):1249-53.

44. Schotte L, Steidler L, Vandekerckhove J, Remaut E. Secretion of biologically active murine interleukin-10 by Lactococcus lactis. Enzyme Microb Technol. 2000;27(10):761-5.

45. Kim H, Jeong Y, Kang S, You HJ, Ji GE. Co-culture with Bifidobacterium catenulatum Improves the growth, gut colonization, and butyrate production of Faecalibacterium prausnitzii vitro and in vivo studies. Microorganisms. 2020;8(5):788 
46. Sun Z, Westermann C, Yuan J, Riedel CU. Experimental determination and characterization of the gap promoter of Bifidobacterium bifidum S17. Bioengineered. 2014;5(6):371-7.

47. Benbouziane B, Ribelles P, Aubry C, Martin R, Kharrat P, Riazi A, Langella P, Bermúdez Humarán LG. Development of a stress-inducible controlled expression (SICE) system in Lactococcus lactis for the production and delivery of therapeutic molecules at mucosal surfaces. J Biotechnol. 2013;168(2):120-9.

48. Mauras A, Chain F, Faucheux A, Ruffié P, Gontier S, Ryffel B, Butel MJ, Langella P, Bermúdez Humarán LG, Waligora Dupriet AJ. A new Bifidobacteria expression system (BEST) to produce and deliver interleukin-10 in Bifidobacterium bifidum. Front Microbiol. 2018;9:3075.

49. Khokhlova EV, Efimov BA, Kafarskaia LI, Shkoporov AN. Heterologous expression of secreted biologically active human interleukin-10 in Bifidobacterium breve. Arch Microbiol. 2010;192(9):769-74.

50. Ng T, Britton GJ, Hill EV, Verhagen J, Burton BR, Wraith DC. Regulation of adaptive immunity; the role of interleukin-10. Front Immunol. 2013;4:129.

51. Vinderola CG, Medici M, Perdigon G. Relationship between interaction sites in the gut, hydrophobicity, mucosal immunomodulating capacities and cell wall protein profiles in indigenous and exogenous bacteria. J Appl Microbiol. 2004;96(2):230-43.

52. Kim YM, Billiar TR, Lancaster JR. Reactive oxygen and nitrogen metabolites and related enzymes. Weir's Handbook Exp Immunol. 1996:4:171.171-171.110

53. Bogdan C, Vodovotz Y, Nathan C. Macrophage deactivation by interleukin 10. J Exp Med. 1991;174(6):1549-55.

54. De Dooy JJ, Mahieu LM, Van Bever HP. The role of inflammation in the development of chronic lung disease in neonates. Eur J Pediatr. 2001;160(8):457-63.

55. Lee MJ, Zang ZL, Choi EY, Shin HK, Ji GE. Cytoskeleton reorganization and cytokine production of macrophages by Bifidobacterial cells and cell-free extracts. J Microbiol Biotechnol. 2002;12(3):398-405.

56. Fiorentino DF, Zlotnik A, Mosmann TR, Howard M, O'garra A. IL-10 inhibits cytokine production by activated macrophages. J Immunol. 1991;147(11):3815-22
57. Ménard O, Butel MJ, Gaboriau Routhiau V, Waligora Dupriet AJ. Gnotobiotic mouse immune response induced by Bifidobacterium sp. strains isolated from infants. Appl Environ Microbiol. 2008;74(3):660-6.

58. Kolios G, Robertson DA, Jordan NJ, Minty A, Caput D, Ferrara P, Westwick J. Interleukin-8 production by the human colon epithelial cell line HT-29: modulation by interleukin-13. Br J Pharmacol. 1996;119(2):351-9.

59. Bai A-P, Ouyang Q, Zhang W, Wang C-H, Li S-F. Probiotics inhibit TNFa-induced interleukin-8 secretion of HT29 cells. World J Gastroenterol. 2004;10(3):455

60. Wang P, Wu P, Anthes JC, Siegel MI, Egan RW, Billah MM. Interleukin-10 inhibits interleukin-8 production in human neutrophils. 1994.

61. Imaoka A, Shima T, Kato K, Mizuno S, Uehara T, Matsumoto S, Setoyama H, Hara T, Umesaki Y. Anti-inflammatory activity of probiotic Bifidobacterium: enhancement of $\mathrm{IL}-10$ production in peripheral blood mononuclear cells from ulcerative colitis patients and inhibition of IL- 8 secretion in HT-29 cells. World J Gastroenterol. 2008;14(16):2511.

62. Sun Z. Development of gene expression systems in Bifidobacterium bifidum S17 and their application for tumor therapy. 2014; Universität UIm.

63. Osswald A, Westermann C, Sun Z, Riedel CU. A phytase-based reporter system for identification of functional secretion signals in Bifidobacteria. Plos ONE. 2015;10(6):e0128802.

64. Stumhofer JS, Silver JS, Laurence A, Porrett PM, Harris TH, Turka LA, Ernst M, Saris CJM, O'Shea JJ, Hunter CA. Interleukins 27 and 6 induce STAT3-mediated T cell production of interleukin 10. Nat Immunol. 2007:8(12):1363-71.

\section{Publisher's Note}

Springer Nature remains neutral with regard to jurisdictional claims in published maps and institutional affiliations.
Ready to submit your research? Choose BMC and benefit from:

- fast, convenient online submission

- thorough peer review by experienced researchers in your field

- rapid publication on acceptance

- support for research data, including large and complex data types

- gold Open Access which fosters wider collaboration and increased citations

- maximum visibility for your research: over $100 \mathrm{M}$ website views per year

At BMC, research is always in progress.

Learn more biomedcentral.com/submissions 